\title{
Response of bell pepper to water replacement levels and irrigation times ${ }^{1}$
}

\author{
Álvaro Henrique Cândido de Souza², Roberto Rezende², \\ Marcelo Zolin Lorenzoni² ${ }^{2}$ Fernando André Silva Santos ${ }^{2}$, Jhonatan Monteiro de Oliveira ${ }^{2}$
}

\section{ABSTRACT}

Different irrigation times result in variable transpiration rates, due to the water availability and its interaction with the evapotranspiration demand. The vapor pressure deficit is an accurate indicator of the atmosfere evaporative capacity and can affect plants because of the movement of water in the soil-plantatmosphere continuum system. This study aimed to evaluate the plant growth, yield and water-use efficiency of bell peppers under irrigation times ( 8 a.m. and 2 p.m.) and water replacement levels $(60 \%, 80 \%, 100 \%, 120 \%$ and $140 \%$ of the crop water requirement - ETc) based on the evapotranspiration demand. The increase in the irrigation levels could be fit to linear models for the variables number of fruits per plant, mean and total fruit weight per plant, fruit length, and root, stem and total dry weight. Irrigation at 2 p.m. increased the total and mean fruit weight and number of fruits per plant, as well as fruit length, if compared to the irrigation at 8 a.m., besides increasing the yield by $50.82 \%\left(2,343.0\right.$ g plant $^{-1}$ to $3,533.6$ g plant $\left.^{-1}\right)$ and the water-use efficiency by $55.64 \%$. In areas subjected to water shortages, establishing irrigation times based on irrigation management practices can increase the water-use efficiency and yield for bell peppers.

KEYWORDS: Capsicum annuum L., vapor pressure deficit, water-use efficiency.

\section{INTRODUCTION}

Bell pepper (Capsicum annuum L.) is among the ten most social and economically important vegetables in Brazil (Lorenzoni et al. 2016). It requires a regular supply of water throughout its growth cycle, but water accumulation in the soil should be avoided, since it favors diseases (Carvalho et al. 2011) and leads to hypoxia.

The water energy state in plants results from the interaction between the water available near the

\section{RESUMO}

Resposta de pimentão a níveis de reposição hídrica e horários de irrigação

Diferentes horários de irrigação resultam em diferentes taxas de transpiração, devido à disponibilidade de água e sua interação com a demanda evapotranspirativa. O déficit de pressão de vapor é um indicador preciso da capacidade evaporativa da atmosfera e pode afetar as plantas, devido ao movimento da água no sistema contínuo solo-planta-atmosfera. Objetivou-se avaliar o crescimento, produtividade e eficiência do uso da água de pimentões submetidos a horários (08:00 h e 14:00 h) e níveis de reposição hídrica $(60 \%, 80 \%, 100 \%, 120 \%$ e $140 \%$ da necessidade hídrica da cultura - ETc) baseados na demanda evapotranspirativa. O aumento nos níveis de irrigação puderam ser ajustados ao modelo linear para as variáveis número de frutos por planta, peso médio e total de frutos por planta, comprimento dos frutos e peso seco da raiz, do caule e total. A irrigação às 14:00 $\mathrm{h}$ aumentou o peso total e médio e o número de frutos por planta, bem como o comprimento dos frutos, se comparada à irrigação às $08: 00 \mathrm{~h}$, além de aumentar a produtividade em 50,82 \% (2.343,0 g planta $^{-1}$ para 3.533,6 g planta $\left.^{-1}\right)$ e a eficiência do uso da água em 55,64\%. Em áreas sujeitas à escassez de água, o estabelecimento de horários de irrigação baseados em práticas de manejo de irrigação pode aumentar a produtividade e a eficiência no uso de água em pimentões.

PALAVRAS-CHAVE: Capsicum annuum L., déficit de pressão de vapor, eficiência no uso de água.

roots, related to absorption, and atmospheric demand, represented by transpiration (Andriolo 1999).

The irrigation management can provide economic, environmental and social advantages. As such, farmers are under an increasing pressure to achieve better yields with smaller water supplies.

With respect to irrigation management and considering the water movement in the soil-plantatmosphere continuum, studies have primarily evaluated the effect of irrigation levels and frequency, soil type, pulse rate and evapotranspiration estimation 
techniques by relating plant growth and yield to soil water status (Frizzone et al. 2001, Dermitas \& Ayas 2009, Gadissa \& Chemeda 2009, Aragão et al. 2011, Carvalho et al. 2011, Aladenola \& Madramootoo 2014). However, few studies have assessed the effect of the atmospheric characteristics that guide irrigation management practices.

The Penman-Monteith equation depends on two primary components (radiation and advection), which increase or decrease in response to other variables (Boulard \& Jemma 1993). Medrano et al. (2005) calculated the theoretical transpiration rate using a transpiration model and compared it to the real measurements during cucumber growth cycles, obtaining satisfactory coefficients of determination of 0.88 and 0.97 in the fall and spring, respectively.

Among the variables responsible for transpiration, the global solar radiation and vapor pressure deficit are important factors (Medrano et al. 2005). Some studies have considered the vapor pressure deficit in irrigation management (Truffault et al. 2017, Zhang et al. 2017), with the highest transpiration values typically recorded around 12 p.m. Andriolo (1999) observed the onset of increased water absorption and transpiration after 6 a.m. and the highest values at 12 p.m., decreasing thereafter until 6 p.m.

The present study evaluated the effect of irrigation times at low ( 8 a.m.) and high $(2$ p.m. $)$ average vapor pressure deficits and irrigation levels on bell peppers grown in a greenhouse.

\section{MATERIAL AND METHODS}

The study was conducted in a greenhouse located at the Universidade Estadual de Maringá, in Maringá, Paraná state, Brazil $\left(23^{\circ} 25^{\prime} 57^{\prime}\right.$ 'S, $51^{\circ} 57^{\prime} 08^{\prime \prime} \mathrm{W}$ and $542 \mathrm{~m}$ of altitude), from May to September 2015. The local climate is characterized as humid subtropical (Cfa), according to the Köppen's classification (Alvares et al. 2013).

The average temperature and relative humidity during the study period were $20.5{ }^{\circ} \mathrm{C}$ and $75.16 \%$, respectively (Figure 1), with average maximum and minimum temperatures of $30.5^{\circ} \mathrm{C}$ and $13.9^{\circ} \mathrm{C}$.

The ideal temperature for bell pepper cultivation is between $19{ }^{\circ} \mathrm{C}$ and $21{ }^{\circ} \mathrm{C}$ (Filgueira 2003). According to the author, temperatures below $15^{\circ} \mathrm{C}$ and above $35^{\circ} \mathrm{C}$ may damage the plant. In the present study, although the average temperature recorded was within the ideal temperature range, some values were outside these limits. Nevertheless, no plant damage was observed, likely because these extreme temperatures were isolated events and did not last.

The soil was classified as a Dystrophic Red Nitosol, with a clayey texture (Embrapa 2013), and the results for soil physical characterization and chemical analyses $(0-0.20 \mathrm{~m}$ depth) were: fine sand $=72.6 \mathrm{~g} \mathrm{~kg}^{-1}$; coarse sand $=50 \mathrm{~g} \mathrm{~kg}^{-1}$; silt $=120.6 \mathrm{~g} \mathrm{~kg}^{-1}$; clay $=756.8 \mathrm{~g} \mathrm{~kg}^{-1}$; density $=$ $1.01 \mathrm{~g} \mathrm{~m}^{3} ; \mathrm{P}=71.22 \mathrm{mg} \mathrm{dm}^{-3} ; \mathrm{Na}^{+}=59.0 \mathrm{mg} \mathrm{dm}^{-3}$; $\mathrm{K}^{+}=0.35 \mathrm{cmol}_{\mathrm{c}} \mathrm{dm}^{-3} ; \mathrm{Ca}^{+2}=4.38 \mathrm{cmol}_{\mathrm{c}} \mathrm{dm}^{-3}$; $\mathrm{Mg}^{+2}=1.77 \mathrm{cmol}_{\mathrm{c}} \mathrm{dm}^{-3} ; \mathrm{Al}^{+3}=0.0 \mathrm{cmol}_{\mathrm{c}} \mathrm{dm}^{-3} ; \mathrm{H}^{+}=$ $2.48 \mathrm{cmol}_{\mathrm{c}} \mathrm{dm}^{-3} ; \mathrm{pH}\left(\mathrm{CaCl}_{2}\right)=6.0 ; \mathrm{pH}\left(\mathrm{H}_{2} \mathrm{O}\right)=6.80$; organic matter $=9.5 \mathrm{~g} \mathrm{dm}^{-3} ; \mathrm{Cu}=10.34 \mathrm{mg} \mathrm{dm}^{-3}$; $\mathrm{Zn}=15.82 \mathrm{mg} \mathrm{dm}^{-3} ; \mathrm{Fe}=64.18 \mathrm{mg} \mathrm{dm}^{-3} ; \mathrm{Mn}=$ $78.11 \mathrm{mg} \mathrm{dm}^{-3}$.

Liming was performed at 30 days before transplanting, with $0.3 \mathrm{~kg} \mathrm{~m}^{-2}$ of limestone, to increase the soil base saturation to $80 \%$, and basal fertilization at 15 days before transplanting, using $0.5 \mathrm{~kg} \mathrm{~m}^{-2}$ of cattle manure, $40 \mathrm{~kg} \mathrm{ha}^{-1}$ of $\mathrm{N}$ (ammonium sulfate) and $60 \mathrm{~kg} \mathrm{ha}^{-1}$ of $\mathrm{K}_{2} \mathrm{O}$ (potassium chloride). After transplanting, $80 \mathrm{~kg} \mathrm{ha}^{-1}$ of $\mathrm{N}, 120 \mathrm{~kg} \mathrm{ha}^{-1}$ of $\mathrm{P}_{2} \mathrm{O}_{5}$ (simple superphosphate) and $80 \mathrm{~kg} \mathrm{ha}^{-1}$ of $\mathrm{K}_{2} \mathrm{O}$ were applied (Trani 2014).

The bell pepper seedlings (Magali-R hybrid cultivar) were grown in 64-cell trays filled with commercial substrate. The seedlings were transplanted into beds, with rows $1.0 \mathrm{~m}$ apart and $0.5 \mathrm{~m}$ between plants.

The experimental design was completely randomized, with five replicates, in a factorial scheme

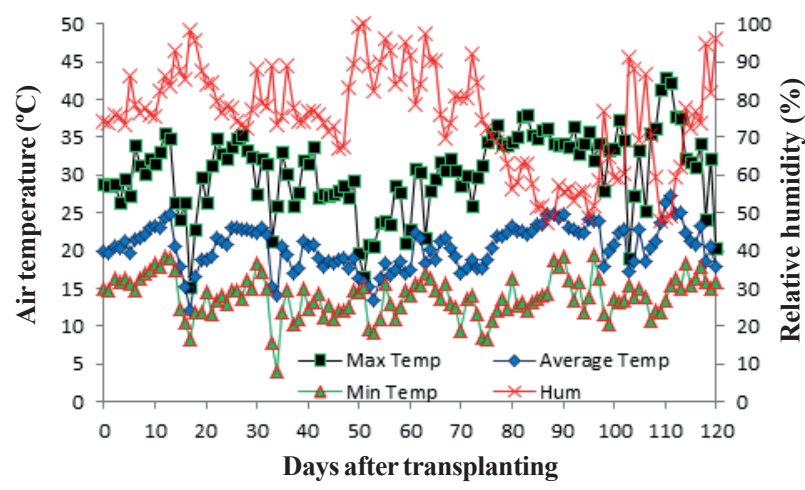

Figure 1. Maximum, average and minimum temperature and relative humidity in Maringá, Paraná state, Brazil, from May to September 2015. 
of five water regimes $(60 \%, 80 \%, 100 \%, 120 \%$ and $140 \%$ of the crop water requirement - ETc) and two irrigation times ( 8 a.m. and 2 p.m.). The experimental unit consisted of six bell pepper plants in each bed. With respect to irrigation times, these corresponded indirectly to the occurrence of low (8 a.m.) and high (2 p.m.) average vapor pressure deficits.

The crop water replacement was based on the evapotranspiration, measured using two constant water table lysimeters (water table at $0.5 \mathrm{~m}$ ), installed at the center of the greenhouse. Each PVC lysimeter had a capacity of $500 \mathrm{~L}$, depth of $0.65 \mathrm{~m}$ and diameter of $1.17 \mathrm{~m}$. The devices were equipped with a tank containing a float valve to maintain a constant water level, with the former connected to a water supply system with known volume, via a flexible tube.

The drip irrigation system was composed of dripping tubes (16 mm wide) with 12 pressurecompensating drippers per tube, spaced $0.25 \mathrm{~m}$ apart, a flow rate of $8 \mathrm{~L} \mathrm{~h}^{-1}$ and an operating pressure of 12 mwc. Irrigation was performed once a day.

The weather data for the experimental period were obtained from a meteorological station installed inside the greenhouse. The relation among temperature, relative humidity and water vapor pressure was obtained by using the Tetens formulas (Truffault et al. 2017): $\mathrm{e}_{\mathrm{s}}=0.6108 * 10^{\wedge}$
$[(7.5 * \mathrm{~T}) /(\mathrm{T}+237.3)]$, where $e_{s}$ is the saturation vapor pressure $(\mathrm{kPa})$ and $T$ the air temperature $\left({ }^{\circ} \mathrm{C}\right)$; $\mathrm{e}_{\mathrm{a}}=\left(\mathrm{RH}^{*} \mathrm{e}_{\mathrm{s}}\right) / 100$, where $e_{a}$ is the partial water vapor pressure $(\mathrm{kPa})$ and $R H$ the relative humidity (\%); and $\mathrm{VPD}=\mathrm{e}_{\mathrm{s}}-\mathrm{e}_{\mathrm{a}}$, where $V P D$ is the vapor pressure deficit $(\mathrm{kPa})$.

The variables analyzed were: number of fruits per plant; yield $\left(\mathrm{g} \mathrm{plant}^{-1}\right)$; average fruit weight ( $\mathrm{g}$ fruit $\left.{ }^{-1}\right)$; fruit length $(\mathrm{mm})$; plant height $(\mathrm{cm})$; stem diameter $(\mathrm{mm})$; root $\left(\mathrm{g}\right.$ plant $\left.{ }^{-1}\right)$, leaf $\left(\mathrm{g} \mathrm{plant}^{-1}\right)$, stem $\left(\right.$ g plant $\left.^{-1}\right)$ and shoot $\left(\right.$ g plant $\left.^{-1}\right)$ dry weight; root, stem and leaf ratio; root/shoot dry weight; harvest index $\left(\mathrm{g} \mathrm{g}^{-1}\right)$; and water-use efficiency $\left(\mathrm{g} \mathrm{mm}^{-1}\right)$.

The analysis of variance was performed to evaluate the differences between treatments, using the Sisvar software (Ferreira 2014). The regression analysis was applied when the F-test demonstrated significance at 0.05 for irrigation levels, and the Tukey test in the event of an unsatisfactory fit for the regression coefficients $(p>0.05)$. The Tukey test was used to analyze the effects of the irrigation times $(\mathrm{p}<0.05)$.

\section{RESULTS AND DISCUSSION}

The variables analyzed under irrigation levels and times are presented in Table 1. The number of

Table 1. Effect of irrigation levels and times on bell peppers yield, under greenhouse conditions.

\begin{tabular}{|c|c|c|c|c|c|c|}
\hline Source of variation & Irrigation times (IT) & Irrigation levels (IL) & IT x IL & Error & \multirow{3}{*}{$\mathrm{CV}(\%)$} & \multirow{3}{*}{ Mean } \\
\hline DF & 1 & 4 & 4 & 40 & & \\
\hline Variable & & - Mean squar & & & & \\
\hline NFP & $598.58 * *$ & $408.65 * *$ & $46.43^{\mathrm{ns}}$ & 49.74 & 17.76 & 39.70 \\
\hline $\mathrm{Y}$ & $17,720,092.71 * *$ & $598,453.33 * *$ & $438,113.44^{\mathrm{ns}}$ & $316,236.11$ & 19.14 & $2,938.32$ \\
\hline AFW & $4,070.90 * *$ & $651.40 * *$ & $110.74^{\mathrm{ns}}$ & 121.04 & 15.09 & 72.93 \\
\hline FL & $8,543.59 * *$ & $801.20^{\mathrm{ns}}$ & $261.99^{\mathrm{ns}}$ & 334.00 & 24.10 & 75.83 \\
\hline $\mathrm{PH}$ & $40.86^{\mathrm{ns}}$ & $98.00^{\mathrm{ns}}$ & $35.28^{\mathrm{ns}}$ & 112.59 & 10.63 & 99.86 \\
\hline $\mathrm{SD}$ & $0.94^{\mathrm{ns}}$ & $1.30^{\mathrm{ns}}$ & $0.87^{\mathrm{ns}}$ & 2.44 & 12.69 & 12.32 \\
\hline RDW & $1.93^{\mathrm{ns}}$ & $31.05^{\mathrm{ns}}$ & $9.66^{\mathrm{ns}}$ & 12.41 & 35.76 & 9.85 \\
\hline LDW & $5.80^{\mathrm{ns}}$ & $29.92^{\text {ns }}$ & $13.59^{\text {ns }}$ & 15.23 & 55.71 & 7.01 \\
\hline STDW & $1.19^{\mathrm{ns}}$ & $241.91 * *$ & $79.85^{\mathrm{ns}}$ & 52.21 & 24.53 & 29.46 \\
\hline SHDW & $1.73^{\mathrm{ns}}$ & $419.89 * *$ & $140.94^{\mathrm{ns}}$ & 102.86 & 27.82 & 36.46 \\
\hline RR & $0.0004^{\mathrm{ns}}$ & $0.00104^{\mathrm{ns}}$ & $0.0008^{\mathrm{ns}}$ & 0.0011 & 16.21 & 0.2126 \\
\hline SR & $0.0001^{\mathrm{ns}}$ & $0.0032^{\mathrm{ns}}$ & $0.0011^{\mathrm{ns}}$ & 0.0019 & 6.83 & 0.64 \\
\hline LR & $0.0011^{\mathrm{ns}}$ & $0.0008^{\mathrm{ns}}$ & $0.00098^{\mathrm{ns}}$ & 0.0015 & 26.49 & 0.14 \\
\hline RDW/SHDW & $0.0008^{\mathrm{ns}}$ & $0.0028^{\text {ns }}$ & $0.002^{\mathrm{ns}}$ & 0.0035 & 21.88 & 0.27 \\
\hline HI & $9,627.44 * *$ & $411.13^{\mathrm{ns}}$ & $864.99^{\mathrm{ns}}$ & 598.92 & 36.11 & 67.77 \\
\hline WUE & $299.48 * *$ & $15.68^{*}$ & $12.33^{\mathrm{ns}}$ & 5.04 & 20.03 & 11.21 \\
\hline
\end{tabular}

NFP: number of fruits per plant; Y: yield (g plant $\left.{ }^{-1}\right)$; AFW: average fruit weight (g fruit $\left.{ }^{-1}\right)$; FL: fruit length (mm); PH: plant height (cm); SD: stem diameter (mm); RDW: root dry weight $\left(\mathrm{g} \mathrm{plant}^{-1}\right)$; LDW: leaf dry weight $\left(\mathrm{g} \mathrm{plant}^{-1}\right)$; STDW: stem dry weight ( $\left.\mathrm{g} \mathrm{plant}^{-1}\right)$; SHDW: shoot dry weight (g plant $\left.\mathrm{f}^{-1}\right)$; RR: root ratio; SR: $^{\text {stem ratio; }}$ LR: leaf ratio; HI: harvest index $\left(\mathrm{g} \mathrm{g}^{-1}\right)$; WUE: water-use efficiency $\left(\mathrm{g} \mathrm{mm}^{-1}\right) . *$ Significant at 0.01 of probability; ${ }^{*}$ significant at 0.05 of probability; ${ }^{\text {ns }}$ not significant $(\mathrm{p}>0.05)$, according to the F-test. 
fruits per plant, yield, average fruit weight and wateruse efficiency were significantly influenced by the isolated effect of irrigation levels and times $(p<0.05)$.

The analysis of variance showed a significant individual effect of irrigation times on fruit length and harvest index, and of irrigation levels on stem and shoot dry weight.

Among the studied growth variables (plant height; stem diameter; root, leaf, stem and shoot dry weight), only the stem and shoot dry weight were significantly influenced by the irrigation levels. Given that the shoot dry weight is the sum of the leaf and stem dry weight, and that the leaf dry weight was not affected by the irrigation levels, the stem dry weight was therefore the main growth variable influenced by the irrigation levels (Figure 2c). Aragão et al. (2011) used nitrogen rates and irrigation levels in bell peppers and found that the leaves and stem were generally unaffected by the irrigation levels.
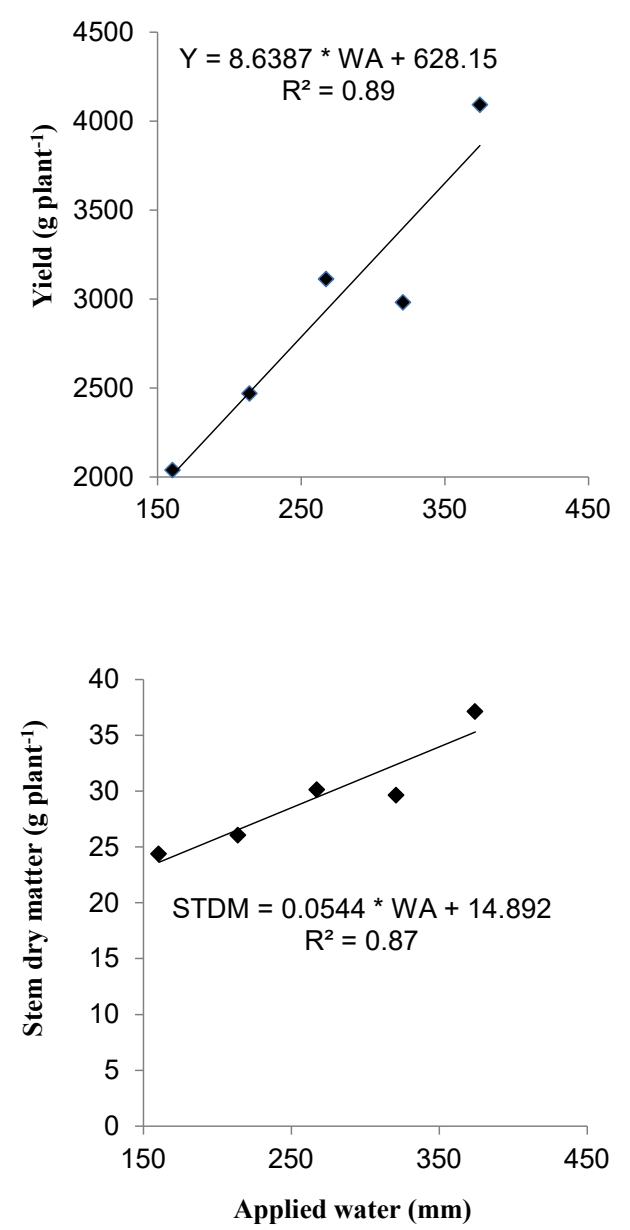

The irrigation levels had no effect on the fruit length and stem diameter, corroborating the results of Padron et al. (2015), who cultivated bell peppers under different irrigation levels, with daily irrigation. The plant height did not differ under the various irrigation levels studied. This behavior contrasts with that observed by Gadissa \& Chemeda (2009), who reported an increase in bell pepper plant height with a rise in the water availability in the soil, and Padron et al. (2015), who obtained the greatest height with $60 \%$ of the ETc $(91.56 \mathrm{~cm})$, if compared to $80 \%$ $(74.75 \mathrm{~cm})$ and $100 \%(72.44 \mathrm{~cm})$ of the ETc.

The irrigation levels had no effect on the leaf dry weight, likely because the unchanged leaf growth reduced the carbon and energy consumption, thus allowing a larger amount of photoassimilates to be distributed to the stem or root system.

The application of water can alter the carbon partitioning, i.e., in some cases, increased irrigation (a)

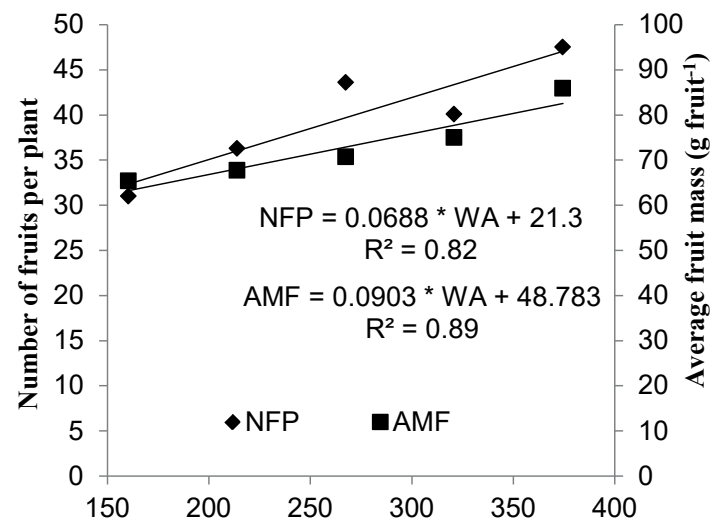

(c)

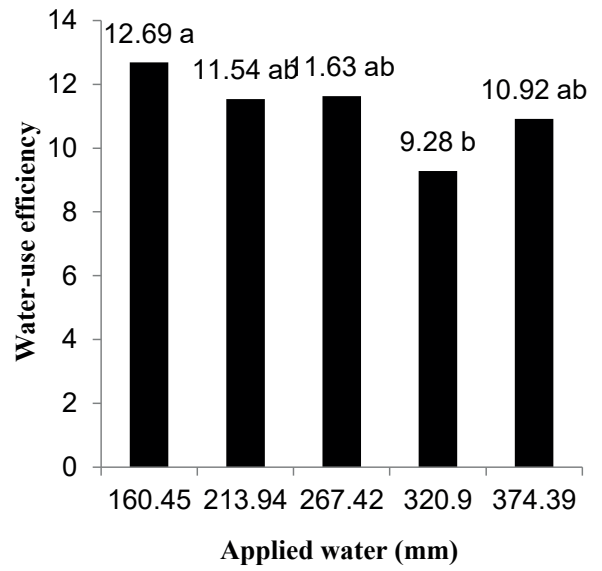

(d)

Figure 2. Yield (A), number of fruits per plant and average fruit weight (B), stem dry weight (C) and water-use efficiency (D) in bell peppers submitted to water levels, in a greenhouse. 
levels reduce the leaf growth and increase the stem growth and yield (Aragão et al. 2011). The fact that the bell pepper studied here is the same hybrid (Magali-R) used by the aforementioned authors supports the hypothesis that the linear increase in the production components was related to the linear increase of the stem, meaning that the stem may have served as a source of assimilates for the fruits.

The largest yield $\left(3,862.3 \mathrm{~g} \mathrm{plant}^{-1}\right.$ or $\left.7,7240.0 \mathrm{~kg} \mathrm{ha}^{-1}\right)$ was obtained under the highest irrigation level $(374.38 \mathrm{~mm}$ or $140 \%$ of the ETc) (Figure 2a), which exceeded $100 \%$ of the ETc, theoretically the ideal level to obtain an optimum yield. However, this may have occurred due to underestimation of the evapotranspiration by the lysimeters. Frizzone et al. (2001) analyzed yellow bell peppers and recorded $37,496.9 \mathrm{~kg} \mathrm{ha}^{-1}$ at the highest irrigation level (490 mm). Díaz-Pérez \& Hook (2017) obtained a quadratic model for yield, as a function of irrigation levels, with the highest yield recorded at $100 \%$ of the ETc.

Dermitas \& Ayas (2009) studied drip-irrigated bell peppers grown in a greenhouse and observed the largest yield $\left(24 \mathrm{tha}^{-1}\right)$ in the treatment with the highest irrigation level (724 mm). Gadissa \& Chemeda (2009) evaluated the effect of three irrigation levels ( $50 \%, 75 \%$ and $100 \%$ of the ETc) on bell pepper yield, and the highest values were obtained with $100 \%$ of the ETc, also obtaining a linear increasing response. However, they also observed a $1.33 \mathrm{~g}$ increase in plants for every $1.0 \mathrm{~mm}$ of water applied. Additionally, the number of fruits per plant increased linearly with rising water levels, obtaining 55 fruits per plant at $100 \%$ of the ETc $(360 \mathrm{~mm})$ (Gadissa \& Chemeda 2009).

The highest number of fruits per plant (47) and average fruit weight $\left(82.58 \mathrm{~g} \mathrm{fruit}^{-1}\right)$ were recorded at $374.38 \mathrm{~mm}$ (Figure 2b). Carvalho et al. (2011) obtained a quadratic response for number of fruits per plant, as a function of irrigation levels, obtaining the highest values at $125 \%$ of the ETc.

The cumulative water applied for the treatments at $60 \%, 80 \%, 100 \%, 120 \%$ and $140 \%$ of the crop evapotranspiration were $160.45 \mathrm{~mm}, 213.93 \mathrm{~mm}$, $267.42 \mathrm{~mm}, 320.9 \mathrm{~mm}$ and $374.38 \mathrm{~mm}$, respectively.

The water-use efficiency showed a linear trend, declining with an increase in the amount of water applied. However, $160.45 \mathrm{~mm}$ (60\% of the ETc) resulted in a significant increase in the water-use efficiency, when compared to $320.9 \mathrm{~mm}$ (120\% of the ETc) (Figure 2d). Similarly, Padrón et al. (2015) observed a decline in the water-use efficiency with an increase in irrigation levels. On the other hand, Aladenola \& Madramooto (2014) recorded the highest water-use efficiency values in bell peppers at $120 \%$ and $100 \%$ of evapotranspiration replacement.

The average vapor pressure deficits data registered were $0.31 \mathrm{kPa}$ at 8 a.m. and $2.1 \mathrm{kPa}$ at 14 p.m., under greenhouse conditions (Figure 3). The highest average vapor pressure deficit $(2.13 \mathrm{kPa})$ was recorded at 3:30 p.m., which is close to the time at which high values were expected ( 2 p.m.). Andriolo (1999) demonstrated that transpiration and water absorption tend to increase at the hottest times of the day, due to the strong evaporative demand.

The irrigation at 2 p.m. increased the number of fruits per plant, yield, average fruit weight, fruit length, harvest index and water-use efficiency (Table 2). The significant differences observed for some production components at different irrigation times can be explained by the interaction between the available water and evaporative demand. Solar radiation, air temperature, humidity and wind speed are the main weather parameters that affect evapotranspiration (Allen et al. 1998). Thus, the vapor pressure deficit can be used to accurately estimate the evaporative capacity.

The irrigation at $2 \mathrm{p} . \mathrm{m}$. increased yield from $2,343.0 \mathrm{~g} \mathrm{plant}^{-1}$ to $3,533.6 \mathrm{~g} \mathrm{plant}^{-1}$, in relation to 8 a.m., corresponding to a significant increase of $50.82 \%$. This result supports the hypothesis that the greatest transpiration occurs when plants are watered at the highest vapor pressure deficit. For cucumber, Medrano et al. (2005) recorded a coefficient of

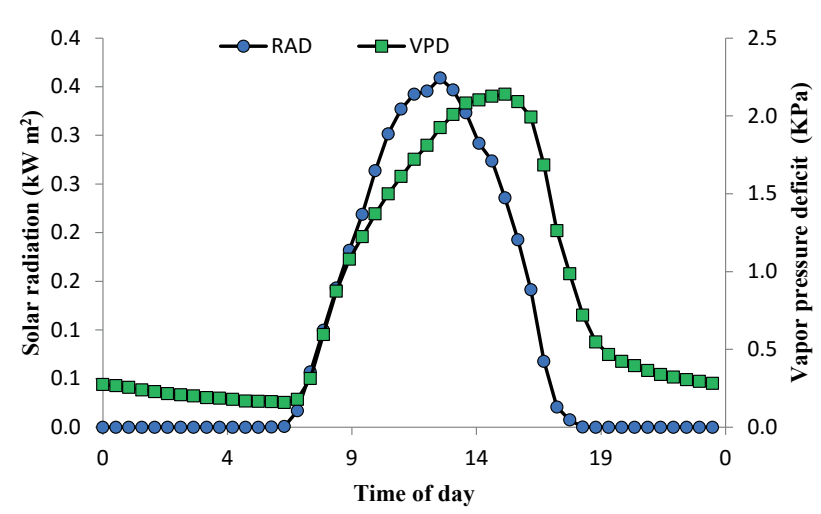

Figure 3. Average solar radiation (RAD) and vapor pressure deficit (VPD) for each time of the day over the study period. 
Table 2. Tukey test for bell peppers at different irrigation times.

\begin{tabular}{lrr}
\hline \multirow{2}{*}{ Variables } & \multicolumn{2}{c}{ Irrigation times } \\
\cline { 2 - 3 } & \multicolumn{1}{c}{$8 \mathrm{a} . \mathrm{m}}$. & $2 \mathrm{p} . \mathrm{m}$. \\
\hline Number of fruits per plant & $36.24 \mathrm{~b}^{*}$ & $43.16 \mathrm{a}$ \\
Yield & $2,343.0 \mathrm{~b}$ & $3,533.64 \mathrm{a}$ \\
Average fruit weight & $63.91 \mathrm{~b}$ & $81.95 \mathrm{a}$ \\
Fruit length & $62.76 \mathrm{~b}$ & $88.91 \mathrm{a}$ \\
Plant height & $98.96 \mathrm{a}$ & $100.76 \mathrm{a}$ \\
Stem diameter & $12.18 \mathrm{a}$ & $12.46 \mathrm{a}$ \\
Root dry weight & $9.65 \mathrm{a}$ & $10.05 \mathrm{a}$ \\
Leaf dry weight & $6.66 \mathrm{a}$ & $7.34 \mathrm{a}$ \\
Stem dry weight & $29.30 \mathrm{a}$ & $29.61 \mathrm{a}$ \\
Shoot dry weight & $36.27 \mathrm{a}$ & $36.64 \mathrm{a}$ \\
Root ratio & $0.20 \mathrm{a}$ & $0.21 \mathrm{a}$ \\
Stem ratio & $0.63 \mathrm{a}$ & $0.64 \mathrm{a}$ \\
Leaf ratio & $0.14 \mathrm{a}$ & $0.15 \mathrm{a}$ \\
Root/shoot dry weight & $0.26 \mathrm{a}$ & $0.27 \mathrm{a}$ \\
Harvest index & $53.89 \mathrm{~b}$ & $81.65 \mathrm{a}$ \\
Water-use efficiency & $8.77 \mathrm{~b}$ & $13.66 \mathrm{a}$ \\
\hline * Averages followed by the same letter in the rows do not differ statistically \\
(p $>0.05$ ) by the Tukey test.
\end{tabular}

determination $\left(\mathrm{R}^{2}\right)$ close to $90 \%$ of the transpiration rate, as a function of the vapor pressure deficit.

Zhang et al. (2017) cultivated tomatoes under two vapor pressure deficit conditions $(1-2 \mathrm{kPa}$ and $4-5 \mathrm{kPa}$ ) and found that lower vapor pressure deficits (1-2 kPa) decreased the driving force for water transport, thereby reducing the water loss and moderating the plant water stress. Their results showed that the biomass and yield increased by $36.8 \%$ and $39.1 \%$, respectively, under low vapor pressure deficits, what was attributed to the efficiency of the atmospheric moisture regulation in reducing the transpiration excess. High vapor pressure deficits lead to stomatal closure, increased transpiration and lower photosynthesis rates (Zhang et al. 2017), thus demonstrating the importance of this indicator in the irrigation management.

Irrigation in the afternoon increased the number of fruits per plant and yield by $19.09 \%$ and $50.82 \%$, respectively, in relation to the irrigation in the morning. The harvest index and water-use efficiency increased by $51.51 \%$ and $55.64 \%$, respectively, for irrigation at 2 p.m., when compared to 8 a.m.

Another factor that may have contributed to the benefits observed for irrigation at 2 p.m. is the constant water flow during the hottest times of the day, consequently regulating nutrients such as potassium.
Despite the benefits obtained by irrigation at 2 p.m., the interference of vapor pressure deficit values and stomatal closing could not be quantified. As such, it is not possible to confirm that the vapor pressure deficit compromised the plant growth at any stage. However, it can be assumed that the combined effects of the irrigation times resulted in considerable differences in the studied variables, such as yield and water-use efficiency.

Farmers should also consider electricity costs when making decisions, because these vary according to the time of the day that electricity is used.

\section{CONCLUSIONS}

1. Irrigation at 2 p.m. is superior to 8 a.m., in terms of number of fruits per plant, yield, average fruit weight, fruit length, harvest index and water-use efficiency;

2. The highest water replacement levels cause significant increases in yield, number of fruits per plant, average fruit weight and shoot dry weight, at both irrigation times.

\section{REFERENCES}

ALADENOLA, O.; MADRAMOOTOO, C. Response of greenhouse-grown bell pepper (Capsicum annuum L.) to variable irrigation. Canadian Journal of Plant Science, v. 94, n. 2, p. 303-310, 2014.

ALLEN, R. G. et al. Crop evapotranspiration: guidelines for computing crop water requirements. Rome: FAO, 1998.

ALVARES, C. A. et al. Köppen's climate classification map for Brazil. Meteorologische Zeits, v. 22, n. 6, p. 711728, 2013.

ANDRIOLO, J. L. Fisiologia das culturas protegidas. Santa Maria: Ed. UFSM, 1999.

ARAGÃO, V. F. et al. Efeito de diferentes lâminas de irrigação e níveis de nitrogênio na fase vegetativa do pimentão em ambiente protegido. Revista Brasileira de Agricultura Irrigada, v. 5, n. 4, p. 361-375, 2011.

BOULARD, T.; JEMMA, R. Greenhouse tomato crop transpiration model: application to irrigation control. Acta Horticulturae, v. 335, n. 1, p. 381-387, 1993.

CARVALHO, J. et al. Análise produtiva e econômica do pimentão-vermelho irrigado com diferentes lâminas, cultivado em ambiente protegido. Revista Brasileira de Engenharia Agrícola e Ambiental, v. 15, n. 6, p. 569-574, 2011. 
DERMITAS, C.; AYAS, S. Deficit irrigation effects on pepper (Capsicum annuum L. Demre) yield in unheated greenhouse condition. Journal of Food, Agricultural and Environment, v. 7, n. 3-4, p. 989-1003, 2009.

DÍAZ-PÉREZ, J. C.; HOOK, J. E. Plastic-mulched bell pepper (Capsicum annum L.) plant growth and fruit yield and quality as influenced by irrigation rate and calcium fertilization. HortScience, v. 52, n. 5, p. 774-781, 2017.

EMPRESA BRASILEIRA DE PESQUISA AGROPECUÁRIA (Embrapa). Centro Nacional de Pesquisa de Solos. Sistema brasileiro de classificação de solos. Rio de Janeiro: Embrapa, 2013.

FERREIRA, D. F. Sisvar: a guide for its bootstrap procedures in multiple comparisons. Ciência e Agrotecnologia, v. 38, n. 2, p. 109-112, 2014.

FILGUEIRA, F. A. R. Solanáceas: agrotecnologia moderna na produção de tomate, batata, pimentão, pimenta, berinjela e jiló. Lavras: Ed. UFLa, 2003.

FRIZZONE, J. A. et al. Produtividade do pimentão amarelo, Capsicum annuum L., cultivado em ambiente protegido, em função do potencial mátrico de água no solo. Acta Scientiarum, v. 23, n. 5, p. 1111-1116, 2001.

GADISSA, T.; CHEMEDA, D. Effects of drip irrigation levels and planting methods on yield and yield components of green pepper in Bako, Ethiopia. Agricultural Water Management, v. 96, n. 11, p. 1673-1678, 2009.

LORENZONI, M. Z. et al. Response of bell pepper crop fertigated with nitrogen and potassium doses in protected environment. Agrotechnology, v. 5, n. 2, p. 1-5, 2016.

MEDRANO, E. et al. Evaluation and modeling of greenhouse cucumber-crop transpiration under high and low radiation conditions. Scientia Horticulturae, v. 105, n. 2, p. 163-175, 2005.

PADRÓN, R. A. R. et al. Supplemental irrigation levels in bell pepper under shade mesh and in open-field: crop coefficient, yield, fruit quality and water productivity. African Journal of Agricultural Research, v. 10, n. 44, p. 4117-4125, 2015.

TRANI, P. E. Calagem e adubação para hortaliças sob cultivo protegido. Campinas: Instituto Agronômico, 2014.

TRUFFAULT, V. et al. Improvement of irrigation and sanitary risk control in a cucumber greenhouse crop using vapor pressure deficit and fruit temperature sensor. Acta Horticulturae, v. 1182, n. 1, p. 129-136, 2017.

ZHANG, D. et al. Vapour pressure deficit control in relation to water transport and water productivity in greenhouse tomato production during summer. Nature, v. 7, n. 1, p. 1-11, 2017. 